\title{
Determinants of High-Performance Organizations in Africa: A Conceptual Framework and Research Propositions
}

\author{
${ }^{*}$ Okechukwu Ethelbert Amah ${ }^{1}$ \\ Kabiru Oyetunde ${ }^{1}$
}

\begin{abstract}
'Lagous Business School, Pinll-Itlentic Iniversity, Liagos, ligeria
The purpose of this study was to develop a conceptual highperformance framework that can be used to gauge how organizations operating in Africa contribute to the sustainability of the continent. This is necessary because literature review showed that the definition of high-performance is contextually located. Also, it was identified that the drive for sustainability made it mandatory for high-performance in Africa to be gauged with the triple bottom line measure. The study argued that organizations operating in the continent should partly be held responsible for social and environmental sustainability in alignment with the United Nations goals on sustainability. Based on these, it was postulated that a mindset change was expected from business leaders to help them recognize the need for the triple bottom line measure of performance. As good corporate citizens, organizations must work to achieve long-term sustainability for the continent and for themselves. Hence, a conceptual model for defining highperformance in the African context was developed along with research proposals for testing the model in future. The study concluded that the conceptual model would ensure that organizations in Africa operate in an ethical manner so as to enhance sustainability in Africa.

Keywords: High-performance, triple bottom line, organizational strategy, sustainability, Africa

JEL:D21, D23, L21, L23
\end{abstract}

Despite the existence of large human and natural resources in Africa, the continent has remained underdeveloped for decades. Foreign Direct Investment (FDI) into Africa grew from \$41 billion in 2017 to $\$ 46$ billion in 2018 (United Nations Trade and Development Report, 2019), yet there was no significant increase in Human Development Index (HDI) and Industrial Production Index (IPI) during this period (HDI from .537 to .539 (.55\%), and IPI from 10\% to 12\%) (International Monetary Fund World Economic Outlook Database, 2019; UNDP African human development report, 2019). Poor and weak foundations inherited from years of colonization, differences in environmental conditions, the African leadership mind-set, and the unsustainable attitudes of organizations in Africa have been proposed as possible reasons for the under-development of Africa (see Amah, 2018). Hence, the authors argue that two major changes are required to turn around the current under-development in Africa. The first is a mindset change of leaders in the continent aimed at redefining the purpose of leadership, and the second is a mindset change of company executives to better understand what constitutes high organi-

Manuscript received June 24, 2019; revised October 21, 2019; accepted

November 15, 2019. @ The Author(s); CC BY-NC; Licensee IJMESS

*Corresponding author: oamah@|bs.edu.ng 
zational performance in Africa. A balanced approach can only be achieved if the two mindset changes are pursued concurrently. The current exploratory paper is geared towards discussing the second mindset change since the first mindset change has been sufficiently covered by Amah (2018). It is argued in this paper that there is a business case for mindset change in organizations to ensure the sustainability of the continent as a condition for their own long-term success. There are two reasons why this should be achieved. The first is that ethical principle demands that when organizations derive benefit from a nation, they should also make effort to ensure the sustainability of that nation (Bulog and Grancic, 2017). The second is that the African economy has potentials for continuous growth in opportunities, and this may position the continent to be the next point of investment for most organizations (Leke, Chironga and Desvaux, 2018; International Monetary Fund World Economic Outlook Database, 2019). To achieve this mindset, three things are required. First, what organizations do and how they do it must consider the entire range of stakeholders. Second, organizations cannot derive survival from a nation and fail to contribute meaningfully to their survival. Third, it makes economic sense when organizations operate with the triple bottom line principle in mind.

The definition of performance and some events in the $21^{\text {st }}$ century also demonstrate the need for the triple bottom line definition of performance. An effective definition of performance incorporates the results obtained (end), defined not in economic terms only, but also in terms of achievement in the social and environmental contexts, and the actions taken to achieve the results (means) which must include how to preserve the social and economic environment in organizational operations. Peters and Waterman (1982) defined excellent organizations on the basis of the economic terms only. Hence, since the ranking was released, questions have been raised as to what constitutes excellent performance for an organization considering the subsequent failures of some of the organizations which made it to the list of excellent organizations. This issue is further compounded by the corporate failures of the $21^{\text {st }}$ century which have been traced to excessive desires for economic excellence and disregard for other measures of excellence. Assessment of high-performance is heavily dependent on the choice of the measurement criteria adopted and is also a function of the predominant philosophy of the organizational leadership. High-performance must align with the internal system of the organization as well as the larger ecosystem which forms the external environment of the organization.

Authors have recommended that any model of high-performance must include the economic, social and environmental criteria (Bhalla et al., 2011; Gelfand, Erez and Aycan, 2007). However, there is still a gap in conceptualizing such a model and testing the same. Hence, the motivation for this exploratory study is to develop a conceptual model on how organizations in Africa should measure high-performance so as to ensure their own sustainability and that of the continent. Unless this is done, organizations may find that there is no continent to return to for their long-term profitability. This 


\section{Amah \& Oyetunde}

exploratory study advocates the principle that organizations can do well by doing good. The study differs from past studies in that most of the other studies only identified the factors that characterize high-performance (Bagorogoza et al., 2013; Cocks, 2012; De Waal, 2012; De Waal and Chipeta, 2015; Nansubuga et a/.,2019), while the current study proposed a conceptual model which incorporates organizational strategy, the characteristics of high-performance organizations, and the triple bottom line performance measures. The study further suggested how the variables in the model can be operationalized and also made future research proposals to test the model.

The exploratory study makes two valuable contributions to define organizational productivity. Firstly, the study developed a conceptual model that accounted for the triple bottom line measure of profitability, namely economic, environmental, and social. To the best of authors' knowledge there exist no other conceptual model that accounted for the economic, social and environmental criteria in defining high-performance in organizations in Africa so as to achieve sustainability in the short and long-run. Secondly, the study developed few propositions and proposed steps to be used in testing them to ascertain the model's usefulness.

The paper contains the following sections. The definition of high-performance and its characterization by past studies in Africa. This is followed by the development of the conceptual model, establishment of relationships in the conceptual model and propositions which can be used to test the relationships. The final section discusses how the variables in the conceptual model can be operationalized by future studies.

\section{LITERATURE REVIEW}

\section{High-Performance Organizations}

Performance is the "the execution of an action and something accomplished" (Merriam Webster, 2008). According to this definition, performance must incorporate the results obtained and the means used to achieve the results. Thus, to build a high-performance organization, both the end and the means must be defined and agreed upon (De Waal and Chipeta, 2015). Prior to the $21^{\text {st }}$ century, most definitions of high-performance identified it in economic terms only (see Cocks, 2012; Peters and Austin, 1985; Peters and Waterman, 1982; Willcoxson, 2000). However, the events of the $21^{\text {st }}$ century have clearly highlighted the shortcomings of defining high-performance narrowly that includes only the requirements of shareholders. There are three foundational facts about high-performance namely: high-performance is not measured in isolation but arises from comparison with peer performance, high-performance is not accidental or intermittent but is achieved through well-articulated and sustainable processes, and the measure of performance incorporates stakeholders' (not only shar- 
eholders') returns. The last aspect is a pointer to the fact that performance measure must go beyond the economic parameter to cover the social and environmental parameters, and that organizations must define stakeholders broadly (Carroll, 2016; De Waal, 2012; Friedman and Miles, 2001). There is abundant evidence that organizations which define performance widely to include the interest of all stakeholders have sustainable growth and profitability (Coomber, 2014).

In order to adequately define what constitutes high-performance considering the expressed desires of organizations, practitioners and researchers have pioneered the drive to establish the basis for measuring and identifying high-performance organizations. This drive cuts across many decades (Koehn, 2012. Within the Western context, organizational performance is understood in terms of creation, building, attributes, and sustenance (see Akdemir, Erden and Polat, 2010; Gudnason and Finnsson, 2017). These studies covered three broad areas: conceptualizing high-performance organizations, identifying the criteria for determining high-performance, and establishing if these criteria vary depending on type and classification of the organization. All these were aimed at determining the factors which distinguished one organization from the other, and the effects of internal and external environment on the organizations. The outcomes of the Western-based definition of highperformance studies are presented in Table 1 (see Appendix-I).

All the studies identified leadership as needed for the definition and implementation of the performance criteria. Apart from such words as sustainability, long term, and future orientation, there is no direct listing of the triple bottom line in the criteria.

\section{High-Performance Organizations in Africa}

Organizations in Africa are likely to function and operate differently from their counterparts in the developed world due to socio-cultural, economic and environmental peculiarities. Gelfand et al. (2007) have argued that national socio-cultural factors play a strong role in how organizations are shaped, coaxed, and modified. Tung (1993) studied Asian managers and found that their major challenge while working in the Western organizations was that mostly they recruit employees from different cultures who view issues differently. Like the Asians, most African countries have different socio-cultural factors when compared to the developed world. The measurement scale to be used in the categorization of high performing organizations in Africa must, therefore, consider the sociocultural, economic and environmental contexts of Africa. Hence, the need to find the factors characterizing high-performance organizations in Africa.

There are two issues with studies that investigate high organizational performance in Africa. The first is that such studies have generally neglected the socio-cultural context of the continent by using the high-performance organization (HPO) framework developed in the Western world, and they do this for 


\section{Amah \& Oyetunde}

either a sector or a single organization (De Waal, 2012; Bagorogoza et al., 2013). The second is that more than necessary emphasis has been placed on the impediments faced by African businesses. Barriers such as corruption, mismanagement, weak institutions, inadequate finance, have been recognized as pervasive in the business environment in Africa. However, opportunities and resources which are capable of driving high-performance in Africa have been left out or casually mentioned. For example, De Waal (2012) stated that lack of requisite knowledge, management skills, and competence have resulted in the inability of developing countries to develop organizational performance management structures and systems. However, some researchers (e.g., Bagorogoza et al., 2013; Van Heerden and Roodt, 2007) tried to benchmark organizations and so came up with internal and external drivers of organizational performance within the African context.

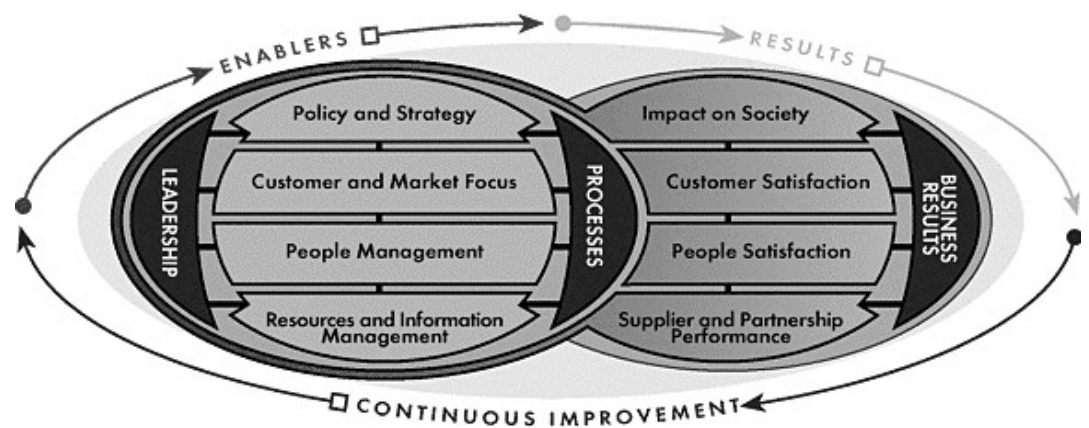

Source: Van Heerden \& Roodt (2007)

Figure 1. The South African Excellence Model

Figure 1 shows the South African Excellence Model (SAEM) proposed by Van Heerden and Roodt (2007). This model is recommended for organizations in Africa to ensure best practices. The SAEM provides the benchmark for comparing organizations in South Africa and for highlighting important areas of improvement. SAEM was developed on the premise that an organization's performance is measured by its impact on the society, satisfaction of its people, customers, suppliers, and other partners. These performance criteria are functions of the company, processes driven by its strategies and policies, focus on customer and market, human resource management, information management, and resource management. The model sees leadership as the main driver pushing for excellence through these components of the organizational process. The SAEM was modeled to better depict what drives performance excellence for organizations in South Africa and other developing countries. While accounting for the social criterion, the model did not explicitly address environmental factors measure organizational performance. 
Boyer, Creech and Paas (2008) developed eight critical success factors and some performance indicators which are requisite for the definition of organizational success and excellence in the context of the developing world. They argued that holistic performance indicators for organizational success benchmark must take into consideration not only economic indicators, but also social and environmental indicators. The eight factors are: leadership, partnership, proof and clarity of innovative concept, planning and marketing, triple bottom line planning, short- and long-term perspectives, community engagement, and risk management.

Hansen, Ishengoma and Upadhyaya (2018) reviewed the drivers for performance variation across

SMEs. They studied the business environment (institutions, infrastructures, linkages) and resources/capabilities (size, technology, capital, human resources policies, leadership) as possible determinants of variation in earnings before interest and tax (EBIT) which is the sole criteria used by the authors to assess high-performance. They found that the quality of business environment, resources, and capabilities differentiated organizations in terms of EBIT. Despite the postulation of these studies, the authors did not find any study that either empirically or conceptually identified the peculiar factors which would characterize high performing organization considering the African economic, socio-cultural and environmental contexts.

Table 2 contains the collated antecedents of high-performance in Africa suggested in this study which were drawn from the studies reviewed and the experiences of the authors. It is argued in this paper that the peculiar nature of African countries makes it necessary to define high-performance based on the triple bottom line perspective of economic, social and environmental performances. This argument is buttressed by the global acknowledgement of social and environmental responsibility as organizational performance criteria (see Carroll, 2016). Thus, high-performance in Africa should be measured by achievement of economic, social and environmental criteria and the consideration of the needs of stakeholders instead of the narrow shareholders' interest used in most definitions. Organizations derive huge benefits from Africa and to ensure the sustainability of the continent, they must contribute to the continent's social and environmental demands.

\section{Conceptual Model of High-Performance in Africa}

Figure 2 shows the high-performance model which presents the positioning of the variables presented in Table 2. Consistent with the belief that strategy drives the behaviors allowed in an organization, the strategy which allows for the triple bottom line principle should drive behaviors which ensure triple bottom line measurement. These behaviors will drive the realizations of the triple bottom line measures of high-performance organizations. The concluding part of this paper will state propositions representing the various relationships in the conceptual model using existing theories in management. 


\section{Amah \& Oyetunde}

Thereafter, recommendation is made on how future studies can implement and test the conceptual model using the propositions developed.

\begin{tabular}{lll}
\hline Areas & Measures for Factors & Performance Indicators \\
\hline Economic/Internal Factors & Resource management/ People management & Financial \\
& Management of short- and long-term benefits & Employee satisfaction \\
& Marketing network and new opportunities & Market coverage \\
& Leadership and managerial ability and capability & Leadership styles \\
& & \\
Social Factors & Strong and viable partnerships & Customer satisfaction \\
& Internal flexibility and dynamism & Community satisfaction \\
& Knowledge and learning culture & \\
& Strong identity & \\
Information management & Number of community \\
& Contributions to social goods & \\
Environmental Factors & Environmental remedy process & \\
& Risk management and impact awareness/assessment & \\
& Community engagement & \\
& &
\end{tabular}

Source: Boyer et al. (2008), Van Heerden \& Roodt (2007), Hansen et al. (2018)

Table 2. High Organizational Performance Factors in Africa

\section{-Strategy and the Triple Bottom Line Factors}

Strategy contains the short- or long-term goals of an organization and the actions required to achieve these goals. These actions are articulated in the strategic plan. Thus, the strategic plan of an organizations contains what the organization wants to achieve, and how it intends to achieve same. The understanding is that when properly articulated and engaged, the actions stipulated in the plan will satisfy what the organization stands for, what it wishes to offer as value proposition to its stakeholders, and what will accrue to the organization. The issue of stakeholder identification and analysis has been a challenge for many decades (Freeman, 1984; Jones, 1995; Walsh, 2005), and is closely linked to the value created by an organization and how high-performance should be defined and captured in the strategy of an organization. Parmar et al. (2001) identified that the concept of stakeholder theory was to address three issues namely: how value is created in organizations, relationship between economic 
value and ethics, and how business practices ethics. These issues also connect to the understanding of what values organizations must create to become high performers. The authors concluded that adopting a better approach to the analysis of stakeholders will address these issues and position organizations for sustainable performance.

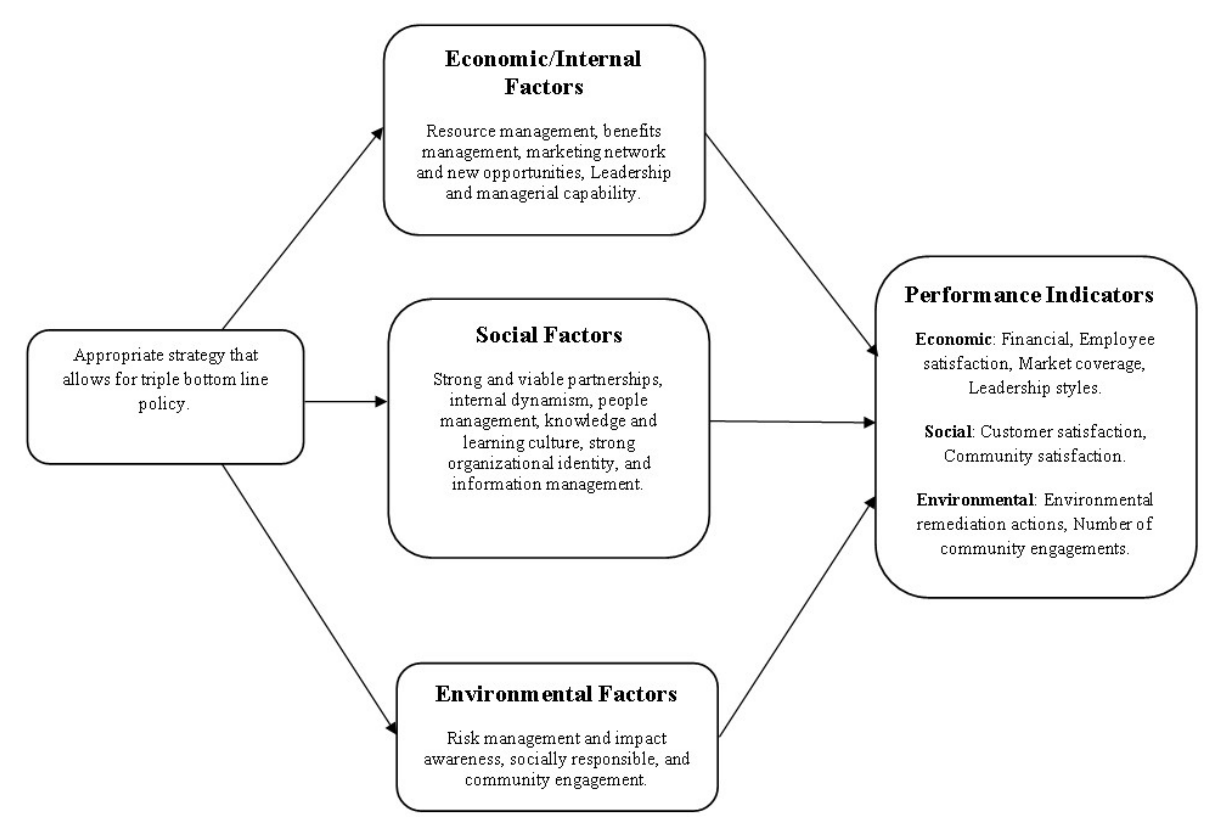

Source: Developed for this study

\section{Figure 1. High-Performance Model for Organizations in Africa}

When profitability is gauged by economic terms alone, the strategic plan will only stipulate actions on achieving economic goals. However, in the high-performance system advocated by the conceptual model, the economic/internal, social and environmental factors must be factored into the strategic plan. In a properly conceptualized triple bottom line high-performance system, the strategic plan will make it mandatory for organizational participants to exhibit only behaviors which will result in the triple bottom line factors in the model. Thus, there should be a link between the strategic plan of the organization and the actions allowed in the triple bottom line factors. For example, if the strategic plan only recognizes economic goals, actions which ensure the triple bottom line will not be stipulated in the plan and will not be encouraged by the organization. The relationship between the organization's strategic plan and the triple bottom line factors will be governed by the cognitive dissonance theory (Festinger and Carlsmith, 1959). This theory states that individuals seek congruence between their beliefs and their behaviors. Whenever there is no congruence, action is taken to resolve the difference 


\section{Amah \& Oyetunde}

between belief and behavior since the individual will not be stable under the situation of incongruence. When applied to an organization, it means that an articulated strategy which accepts triple bottom line performance will elicit behaviors that allow for the economic/internal, social and environmental factors to avoid dissonance. Thus, an organization that espouses the triple bottom line principle in its strategy will behave in line with the triple bottom line behaviors so as to avoid dissonance. Hence, there will be positive relationship between a strategy that allows for triple bottom line performance and the actions under the triple bottom line factors. Based on above argument, the following propositions are advised:

$\mathrm{P}_{1}$ : There is a positive relationship between strategy containing triple bottom line goals and behaviors in the economic/internal factors

$\mathrm{P}_{2}$ : There is a positive relationship between strategy containing triple bottom line goals and behaviors in the social factors

$\mathrm{P}_{3}$ : There is a positive relationship between strategy containing triple bottom line goals and behaviors in the environmental factors

\section{-Behaviors in Triple Bottom Line Factors and Performance Measures}

An organization that allows triple bottom line behaviors must stipulate triple bottom line performance measures. For example, if a company has corporate social responsibility as an action in its strategic plan, it will enact behaviors that ensure the realization of the corporate social responsibility included in its strategic plan, and also utilize measures of performance that capture how well it is doing in its corporate social responsibility plans. It has been demonstrated that when organizational behavior is directed at corporate social responsibility, such actions benefit stakeholders who in turn react favorable to the actions of the organization (Yoo and Lee, 2018). Social exchange, and the norm of reciprocity theories (Blau, 1964; Gouldner, 1960) would explain the relationship between the behaviors in the triple bottom line factors and the triple bottom line criteria for measuring performance. In social exchange relationships, individuals involved must have currencies of exchange to be used in the reciprocal process so as to maintain the relationship. The relationship is terminated when there is no reciprocity. The behaviors stipulated under the triple bottom line factors constitute the currencies provided by the organization in the exchange relationship between it and its stakeholders. Stakeholders' currency includes satisfaction and commitment to the organization. Thus, when an organization exhibits the triple bottom line behaviors, stakeholders, who receive the benefits, are by the norm of reciprocity bound to reciprocate by the way of satisfaction and willingness to maintain relationship with the organization. For example, Yoo and Lee (2018) found that the more the corporate 
social responsibility actions of an organization aligned with the need of stakeholders, the more favorable their customer evaluation. Hence, the following propositions are stated:

$\mathrm{P}_{4}$ : Adopting the behaviors in the economic/internal factors will result in achievement of economic/internal measures of success.

$\mathrm{P}_{5}$ : Adopting the behaviors in social factors will result in the achievement of social measures of success.

$P_{6}$ : Adopting the behaviors in environmental factors will result in the achievement of environmental measures of success.

\section{DISCUSSION}

This paper is aimed at developing a conceptual model of high organizational performance in Africa. Various studies which determined what constitutes high-performance in the Western world were reviewed. The aim is to articulate what past authors in the Western world defined as high-performance. Reviewed studies on high-performance in the Western world indicated that high-performance should be measured using the economic criterion (see De Waal, 2012; Peters and Waterman, 1982). In the Western world, there are effective laws which demand that organizations act as good corporate citizens always. For example, The Enterprise-Reward, August 28, 2018, reported that Californian lawmakers blocked attempts to allow oil drilling wells in California. Based on such laws, researchers may have assumed that organizations would be honest enough to act according to the demands of the laws. Some organizations may have acted accordingly, but the growth of environmental and social activists is an indication that most organizations did not act as good corporate citizens, hence, this drive some studies for organizations to pursue the triple bottom line measures of performance. If this need can be advocated in the Western world where there are laws, Africa needs it more because of non-existent or ineffective laws.

A review of some studies on Africa was also done. From this review, it became obvious that the definition of high-performance is contextually positioned. This means that Africa must look inwards for how best to define high-performance. High-performance in Africa cannot be defined in isolation of the overall sustainable development of the continent. Sustainable development is a joint responsibility of the national leaders and leaders of organizations. Thus, it is highlighted that there must be mind-set changes in national leaders and organizational leaders for sustainable development to occur. Organizations being going concerns, must also work for the sustainability of their operational context. 


\section{Amah \& Oyetunde}

Emphasis on only the economic/internal criterion of success cannot develop sustainability. The mindset change required from organizational leaders is to broaden their horizon to define high-performance from the triple bottom line principle involving economic, social and environmental variables. Organizations are moving into Africa and expanding their businesses because of the expected continuous high economic growth in the continent (Leke et al., 2018). Hence, in spite of the poor performance of national leaders, organizations must go the extra mile to become good corporate citizens so as to protect their current and future investments. One way to do this is to work for the sustainable development of the continent through triple bottom line behaviors.

Many foreign and local companies operating in Africa have realized that their continued success depends on a mind-set which looks beyond the economic measures of success to the triple bottom line measures which ensure long-term survival of the continent and their organizations. They have realized that they can actually "do well, by doing good" (Leke et al., 2018: 177). General Electric believes that their business and social objectives are related. The chairman stated that multinationals must have the mind-set of investing in the "infrastructure of skills-building." Econet Group's Chairman invested a lot in scholarship to alleviate illiteracy and develop skills through mentoring. In his words, "to be successful, you need to be more than a businessman-you need to be a responsible citizen" (Leke et al., 2018: 178). Equity Bank in Kenya was set up to cater for those excluded in financial services by major banks. The bank saw this action as a course for the emancipation of the poor. Initially it was not very profitable, but the more they made sacrifices to go beyond the economic measures to the triple bottom line, the more they grew their financial base. Equity Bank is currently one of the biggest banks in Kenya and is still pursuing its mission to the neglected poor people. The story of Equity bank demonstrates that, in the long term, the mind-set of the triple bottom line yields dividends. Individuals in Africa have also seen the need to have the triple bottom line mind-set. For example, a Nigerian businessman Tony Elumelu explained that the government alone cannot drive the development of the continent. He has instituted a philosophy aimed at creating economic prosperity and social wealth. Fred Swaniker who founded the Africa Leadership University believes that organizations that do well and will continue to do well are those who are not narrow in their definition of success but broadly encompass the triple bottom line measures of success. Some organizations in Africa are linking their involvement in Africa to helping the continent fulfil the United Nations' sustainability development goals (SDGs). The UN sustainability goals go beyond the economic factor and include factors such as "poverty, inequality, climate, environmental degradation, prosperity, and peace and justice" (United Nations, n.d.). This is an indication that some organizations in Africa believe in the principle that "money does grow on trees in Africa." The examples above have demonst- 
rated that the concept of triple bottom line measure of productivity has a long-term effect which will benefit the organizations and the context of their businesses. It ensures that organizations do not milk dry the goose that lays the golden egg without caring for it, so that it may lay more and better golden eggs.

Records show that when organizations in Africa neglect the above, negative consequences follow which will eventually destroy what they have achieved economically. For example, Onwubiko et al. (2013) believed that it was the failure of the oil companies operating in the Niger Delta region of Nigeria that led to the activities of the militants. Premium Times (February 15, 2019) reported that the activities of the militants cost the Nigerian government $\$ 5.83$ billion and 40 percent of the operating expenses of the oil companies in 2016. The oil companies paid taxes to the government and expected the government to handle the social and environmental demands of their host communities. This, however, did not happen, and so the communities felt that their social and environmental needs were neglected while the environment was being destroyed beyond repair. The companies expected the communities to direct their grievances to the government, but because the government is a strong, more remotely located and inaccessible authority, the communities directed their hostilities to the near and accessible authorities, using them as proxies for the inaccessible authority.

A possible argument against the recommendation of the triple bottom line concept is that, demanding that organizations in Africa conform to these criteria will make them less competitive compared to those from other continents. However, this concern can be looked in two ways. Organizations can either choose to continue to milk the goose that lays the golden egg until it dies, and they too will eventually die, or they can take care of the goose to produce better golden eggs and enhance their performance. It is a choice between unsustainable short-term productivity and sustainable long-term productivity. The authors argue in this paper that it is time Africa took care of her environment and demand that organizations operating in the continent behave in ways that will benefit the continent. This is not being unreasonable since management scholars have recognized that high-performance must be contextually defined to be meaningful.

\section{IMPLICATIONS}

Theoretically, this study makes valuable contribution to the development of conceptual model of highperformance which when tested can help in the sustainability drive in Africa. It linked the cognitive dissonance, social, and reciprocity theories to the relationships involving organizations' emphasis on economic, social and environmental factors (triple bottom line measures) in their strategic plan, to the enactment of behaviors that encourage the triple bottom line emphasis, and the achievement of triple 


\section{Amah \& Oyetunde}

bottom line results. Managerial implication is that organizational leaders must emphasize the triple bottom line factors in their strategy and encourage behaviors that achieve same in their organizations. In this way they could create environment that could achieve sustainability in the context of their operations.

\section{FUTURE DIRECTIONS}

A major contribution of this paper is the development of a conceptual model (African HighPerformance Organization - AHPO) which incorporates the triple bottom line concept of highperformance recommended in the paper. Using available theories, the authors articulated various propositions which link various components of the model. However, future studies can test the validity of these propositions to ascertain the accuracy and need for modification. The authors do not claim to have included all the behaviors in a triple bottom line concept; future researchers should seek for more behaviors using the conceptual model as a guide. Future studies should start by developing appropriate measures for each of the components of the model. There is a need to develop measures for strategy which allows the triple bottom line concept of high-performance. The use of existing measures of strategy may pose some challenges because most of the existing strategy measures incorporate only economic goals. It is, therefore, recommended that the starting point for future research should be developing and validating a strategy measure that incorporates the triple bottom line goals. The various behaviors in the economic/internal, social and environment factor must be developed. A highlighted problem in the adoption of the triple bottom line is how to make the social and environmental factors as objective and quantifiable as the economic factor. It will be recalled that the measurement of behavioral criteria in performance management system faced the same criticism. However, ways have been found to make such measures less subjective. Future studies should develop less subjective measures of social and environmental criteria through an empirical endeavor.

The final measures are those which measure the satisfaction of all the stakeholders in the triple bottom line concept model. Stakeholders include the internal and external stakeholders of the organization. It will also be necessary to identify control variables which must be included in the model.

\section{REFERENCES}

Akdemir, B., Erdem, O. \& Polat, S. (2010). Characteristics of high-performance organizations. Süleyman Demirel Üniversitesi I ktisadi ve I dari Bilimler Fakültesi Dergisi, 15(1): 155-174.

Amah, O.E. (2018). Globalisation and leadership in Africa: Developments and challenges for the future. Cham, Switzerland: Palgrave Macmillan

American Management Association. (2007). How to build a high-performance organization: A global study of current trends and future possibilities 2007- 2017. New York: AMA.

Bagorogoza, J., De Waal, A., Van den Herik, H. J. \& Van de Walle, B. A. (2013). A critical assessment of the high-performan- 
ce framework in the Ugandan financial sector. Botswana Journal of Business, 6(1): 1-16.

Bhalla, V., Caye, J. M., Dyer, A., Dymond, L., Morieux, Y. \& Orlander, P. (2011). High-Performance Organizations. Own the Future: 50 Ways to Win. The BostonConsulting Group, 171-177.

Blau, P. (1964). Exchange and power in social life. New York: Wiley.

Boyer, D., Creech, H. \& Paas, L. (2008). Critical success factors and performance measures for start-up social and environmental enterprises. Report for SEED Initiative Research Programme, 115-139.

Bulog, I. \& Grancic, I. (2017). The benefits of business ethics-ethical behavior of decision makers: The empirical findings from Croatia. Mediterranean Journal of Social Sciences, 8(4): 8-14.

Carroll, A. B. (2016). Carroll's pyramid of CSR: Taking another look. International Journal of Corporate Social Responsibility, $1(1): 1-8$.

Cocks, G., (2012). Creating benchmarks for high performing organizations. International Journal of Quality and Service Sciences, 4(1): 16-26.

Coomber, S. (2014). Doing well by doing good. London Business School Review, 25(1): 6

De Waal, A. A. (2012). Characteristics of high-performance organizations. Journal of Management Research, 8(3): 39-71.

De Waal, A. \& Chipeta, K. 2015. Influence of culture on priority-setting of high-performance activities. Journal of Strategy and Management, 8(1): 64-86.

Festinger, L., \& Carlsmith, J. M. (1959). Cognitive consequences of forced compliance. Journal of Abnormal and Social Psychology, 58(1): 203-210.

Freeman, R. E. (1984). Strategic management: A stakeholder approach. Boston:

Pitman Publishing Inc.

Friedman, A. L. \& Miles, S. (2001). Developing a Stakeholder Theory. Journal of Management and Studies, 39(1): 1-21.

Gelfand, M. J., Erez, M. \& Aycan, Z. (2007). Cross-cultural organizational behavior. Annual Review Psychology, 58, 479-514.

Gouldner, A.W. (1960). The norm of reciprocity: A preliminary statement', Americana Sociological Review, 25, 161-171.

Gudnason, S. \& Finnsson, T.R. (2017). The search for high-performance in organizations - A study of the CHPS framework. Unpublished master's dissertation, Lund University, Sweden.

Hansen, M. W., Ishengoma, E. K. \& Upadhyaya, R. (2018). What constitutes successful African enterprises? A survey of performance variations in 210 African food Processors. International Journal of Emerging Markets, 13(6): 1835-1854.

International Monetary Fund. (2019). World economic outlook database. Retrieved 15 October 2019, from https://www.imf.org/external/pubs/ft/weo/2019/02/weodata/index.aspx.

Jones, T. M. (1995). Instrumental stakeholder theory: A synthesis of ethics \& economics. Academy of Management Review, 20 , 404-437.

Koehn, N. (2012). A brief history of doing well by doing good. Harvard Business Review. Retrieved from https://hbr.org/2012/06/a-brief-history-of-doing-well.

Leke, A., Chironga, M. \& Desvaux, D. (2018). Africa's business revolution: How to succeed in the world's next big growth market. Boston, MA: Harvard Business Review Press.

Merriam-Webster. (1996). Online Dictionary. Retrieved from https://www.merriam-webster.com/.

Nansubuga, F., Munene, J. C., Kikooma, J., Nansamba, J. \& Masanje, K. (2019). An effective learning culture: Using highperformance work systems to strengthen the relationship between communities of practice and knowledge creation in Africa. African Management Journal, 5(2): 162-181.

Onwubiko, O.F., Azizan, K., Khairuddin, I. \& Jamilah, O. (2013). The causes, effects and potential solutions to the deep-rooted Niger Delta oil crisis. International Journal of Social and Behavioural Sciences, 1(6): 122-129.

Owen, K., Mundy, R., Guild, W., \& Guild, R. (2001). Creating and sustaining the high-performance organization. Managing Service Quality: An International Journal, 11(1): 10-21.

Parmar, B. L., Freeman, R. E., Harrison, J. S., Wicks, A. C., de Colle, S. \& Purnell, L. (2010). Stakeholder theory: The state of the art. The Academy of Management Annals, 3(1): 403-445.

Peters, T. J. \& Austin, N. (1985). A passion for excellence - The leadership difference. London: HarperCollins Publishers.

Peters, T. \& Waterman, R. (1982). In search of excellence: Lessons from America's best-run corporations. New York: Warner.

Tung, R. L. (1993). Managing cross-national and intra-national diversity. Human Resource Management, 32(4): 461-477.

United Nations. (n.d.). About the sustainable development goals. Retrieved from https://www.un.org/sustainabledevelopment/sustainable-development-goals/.

United Nations (2019). United Nations trade development report. Retrieved from https://unctad.org/en/PublicationsLibrary/tdr2018_en_pdf.

UNDP. (2019). UNDP Africa human development report. Retrieved 15 October 2019, from https://www.undp.org/content/undp/en/home/librarypage/hdr/2019-africa-human-development-report.html.

Van Heerden, W. \& Roodt, G. (2007). The development of a measuring instrument for assessing a high-performance culture. SA Journal of Industrial Psychology, 33(1): 18-28.

Walsh, J. P. (2005). Taking stock of stakeholder management. Academy of Management Review, 30(2): 426- 438.

Willcoxson, L., (2000). Defining and creating a high-performance organization. Australian Journal of Management and Organizational Behavior, 4(1): 100-106.

Yoo, D. \& Lee, J. (2018). The effects of corporate social responsibility (CSR) fit and CSR consistency on company evaluation: The role of CSR. Sustainability, 10, 1-16. 


\begin{tabular}{|c|c|c|c|}
\hline Authors & Definitions & Distinguishing Criteria & Context \\
\hline $\begin{array}{l}\text { American } \\
\text { Management } \\
\text { Association } \\
(2007)\end{array}$ & $\begin{array}{l}\text { Organizations that } \\
\text { are so outstanding } \\
\text { that they } \\
\text { continuously perform } \\
\text { better than } \\
\text { competitors over a } \\
\text { long period of time. }\end{array}$ & $\begin{array}{l}\text { Strategic Approach } \\
\text { Sustainability } \\
\text { Processes and Structure } \\
\text { Values and Beliefs } \\
\text { Customer Approach }\end{array}$ & $\begin{array}{l}\text { United States of America } \\
\text { (USA) }\end{array}$ \\
\hline $\begin{array}{l}\text { Bhalla et al. } \\
\text { (2011) }\end{array}$ & $\begin{array}{lr}\begin{array}{l}\text { Organizations } \\
\text { energized }\end{array} & \text { with } \\
\text { engaged } & \text { and } \\
\text { confident } & \text { strategy, } \\
\text { and } & \text { change } \\
\text { embracing. }\end{array}$ & $\begin{array}{l}\text { Effective strategy } \\
\text { Level of people engagement } \\
\text { Change Management } \\
\text { Culture and Engagement } \\
\text { Design }\end{array}$ & Asia-Pacific \\
\hline Cock (2012) & $\begin{array}{l}\text { HPOs live in the way } \\
\text { they wish to live their } \\
\text { dreams. }\end{array}$ & $\begin{array}{l}\text { Effective Execution } \\
\text { Perfect Alignment } \\
\text { Adapt Rapidly } \\
\text { Externally Focused } \\
\text { Right People } \\
\text { Manage Downside } \\
\text { Balancing strategy and environmental changes }\end{array}$ & Australia \\
\hline $\begin{array}{l}\text { De Waal } \\
(2012)\end{array}$ & $\begin{array}{l}\text { Better financial } \\
\text { results among peers } \\
\text { over a longer period } \\
\text { of time, quick } \\
\text { adaptation r to } \\
\text { changes, integrated } \\
\text { and aligned } \\
\text { management } \\
\text { structure, continuous } \\
\text { improvement, and } \\
\text { value employees. }\end{array}$ & $\begin{array}{l}\text { Organizational Design } \\
\text { Strategy } \\
\text { Process Management } \\
\text { Technology } \\
\text { Values people } \\
\text { Culture } \\
\text { External Orientation } \\
\text { Sustainability } \\
\text { Continuous improvement } \\
\text { Culture } \\
\text { External Orientation }\end{array}$ & $\begin{array}{l}\text { Meta-Analysis of } 91 \\
\text { empirical studies from } \\
\text { different countries (but } \\
\text { not stated). }\end{array}$ \\
\hline $\begin{array}{l}\text { De Waal } \\
(2012) \text { (HPO } \\
\text { Framework) }\end{array}$ & $\begin{array}{l}\text { Better financial and } \\
\text { non-financial results } \\
\text { among peer groups } \\
\text { over a period of not } \\
\text { less than five years. }\end{array}$ & $\begin{array}{l}\text { Openness and Action Orientation } \\
\text { Long Term Orientation } \\
\text { Continuous Improvement and Renewal } \\
\text { Quality of Employees }\end{array}$ & $\begin{array}{l}\text { Meta-analysis and global } \\
\text { survey. However, context } \\
\text { not clearly specified. }\end{array}$ \\
\hline $\begin{array}{l}\text { Owen et al. } \\
\text { (2001) }\end{array}$ & $\begin{array}{l}\text { Able to continuously } \\
\text { respond to and } \\
\text { sustain attitude } \\
\text { needed to meet } \\
\text { marketplace } \\
\text { expectations. }\end{array}$ & $\begin{array}{l}\text { Customer focused } \\
\text { Agile organization } \\
\text { Externally driven } \\
\text { Shared and Aligned Strategic Intent } \\
\text { Infrastructures } \\
\text { Employee Behavior }\end{array}$ & United States \\
\hline $\begin{array}{l}\text { Peters and } \\
\text { Austin (1985) }\end{array}$ & $\begin{array}{l}\text { Better financial } \\
\text { results }\end{array}$ & $\begin{array}{l}\text { People } \\
\text { Customer Care } \\
\text { Constant Innovation }\end{array}$ & United States \\
\hline $\begin{array}{l}\text { Willcoxson } \\
(2000) \text {. }\end{array}$ & $\begin{array}{l}\text { Financial or service } \\
\text { performance of a } \\
\text { firm in comparison } \\
\text { with a pre-conceived } \\
\text { set of expectations or } \\
\text { in distinction from } \\
\text { other's achievements. }\end{array}$ & $\begin{array}{l}\text { Fundamental criteria for High-performance: } \\
\text { 1. Internal Structures } \\
\text { 2. Technical System } \\
\text { 3. Human System } \\
\text { 4. Communication } \\
\text { 5. Resourcing System }\end{array}$ & Australia \\
\hline
\end{tabular}

Table 1. Conceptualization of High-Performance Organizations 